\title{
Formulary Management of 2 New Agents: Lorcaserin and Phentermine/Topiramate for Weight Loss
}

\author{
Elizabeth M. Kelly, PharmD; Alexandra A. Tungol, PharmD; and Laurie A. Wesolowicz, PharmD
}

\begin{abstract}
BACKGROUND: Obesity may lead to the development of multiple chronic disease states, including hypertension, dyslipidemia, and type 2 diabetes mellitus. Over a half billion adults worldwide are affected by obesity, and more than two-thirds of adults are either obese or overweight in the United States. Diet and exercise have been the mainstays of treatment in this population; however, once failed, noninvasive, long-term effective treatment modality is lacking, and medications may potentially fill the void. Lorcaserin and phentermine/topiramate were approved by the FDA in June 2012 and July 2012, respectively, as adjuncts to diet and exercise for chronic weight management of obese (body mass index $[\mathrm{BMI}] \geq 30 \mathrm{~kg} / \mathrm{m}^{2}$ ) or overweight $\left(B M I \geq 27 \mathrm{~kg} / \mathrm{m}^{2}\right)$ individuals with comorbidities.

OBJECTIVE: To review the phase 3 trials of lorcaserin and phentermine/ topiramate and provide managed care considerations that may be taken into account as a result.

METHODS: A MEDLINE review was performed for articles published and available through September 17, 2012, using keywords "Iorcaserin" or "phentermine/topiramate" with an emphasis on phase 3 trials. The literature search was limited to randomized controlled trials in humans published in the English language. Additional information on lorcaserin from its FDA review was obtained from the FDA website.
\end{abstract}

RESULTS: 5 pivotal phase 3 trials were identified: 3 for lorcaserin and 2 for phentermine/topiramate. Both agents demonstrated a statistically significant higher proportion of individuals who lost $\geq 5 \%$ of body weight, as well as higher mean weight loss when compared with placebo. Safety concerns for lorcaserin include cardiac valvulopathy and increased risk of psychiatric, cognitive, and serotonergic adverse effects. Teratogenicity and increased heart rate are major safety concerns regarding phentermine/ topiramate.

CONCLUSIONS: Health care decision makers have many factors to consider when developing strategies to fight obesity. Despite a great need for new therapies to treat obesity, medications used for weight loss have significant side-effect profiles and contraindications that may limit therapy. An appropriate utilization management strategy is needed.

J Manag Care Pharm. 2013;19(8):642-54

Copyright $\odot 2013$, Academy of Managed Care Pharmacy. All rights reserved.

\section{What is already known about this subject}

- The standard of care for the treatment of obesity is lifestyle changes, including diet modification and exercise.

- Thirteen years have passed since a weight loss agent has been approved by the FDA (orlistat was approved in 1999).

\section{What this study adds}

- A comprehensive summary of weight loss guidelines is provided, including those from the National Heart, Lung and Blood Institute, U.S. Preventive Services Task Force, American Diabetes Association, and American Heart Association, that emphasize treatment with lifestyle therapy but include some medication recommendations.

- Managed care considerations for coverage of weight loss agents include potential increases in drug utilization; comparative safety and efficacy of therapeutic agents; appropriate utilization management controls; and drug, medical, and overall health care costs.

- Express Scripts and Aetna's coverage of phentermine/topiramate signifies that drugs being used to treat weight loss are being considered similar to those for chronic medical conditions and not lifestyle therapy, setting the stage for smaller pharmacy benefit managers and health plans to potentially follow suit.

$\square$ besity is an epidemic that affects over a half billion adults worldwide and contributes to the development of multiple chronic disease states, including hypertension, dyslipidemia, and type 2 diabetes mellitus (T2DM). According to 2010 statistics, more than two-thirds of U.S. adults are either obese (body mass index [BMI] $\geq 30$ kilogram per square meter $\left.\left[\mathrm{kg} / \mathrm{m}^{2}\right]\right)$ or overweight $\left(\mathrm{BMI} \geq 25 \mathrm{~kg} / \mathrm{m}^{2}\right)^{2}$ Diet modification and exercise have been the mainstays of treatment; however, once failed, few alternatives are available for long-term treatment, such as bariatric surgery and drug therapy. ${ }^{3}$

Pharmacotherapy is indicated for individuals with a BMI $\geq 30 \mathrm{~kg} / \mathrm{m}^{2}$, or those with a BMI $\geq 27 \mathrm{~kg} / \mathrm{m}^{2}$ and diagnosed with comorbidities such as hypertension, dyslipidemia, or T2DM. ${ }^{3}$ Prior to June 2012, the U.S. Food and Drug Administration (FDA) approved drug therapies for obesity in the United States included phentermine, orlistat, benzphetamine, phendimetrazine, methylphenidate, and diethylpropion (Table 1). Off-label drug therapies for obesity include other medications such as topiramate and zonisamide, an antiepileptic and antipsychotic, respectively. ${ }^{3,4}$ Other pharmacotherapy utilized in the past includes multiple drugs that have been discontinued and removed from the market, such as fenfluramine, dexfenfluramine, sibutramine, and mazindol (Table 2). ${ }^{3}$ The drug combination of phentermine and either fenfluramine or 
Formulary Management of 2 New Agents: Lorcaserin and Phentermine/Topiramate for Weight Loss

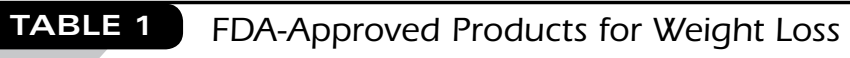

\begin{tabular}{|c|c|c|c|c|c|c|}
\hline Drug & $\begin{array}{c}\text { FDA Approval } \\
\text { Date }\end{array}$ & $\begin{array}{c}\text { Prescription } \\
\text { (Controlled Status) } \\
\text { or OTC Product }^{\mathrm{a}}\end{array}$ & $\begin{array}{l}\text { Short- or } \\
\text { Long-term } \\
\text { Therapya,b }\end{array}$ & $\begin{array}{l}\text { Mechanism of } \\
\text { Action }^{\mathrm{a}}\end{array}$ & Common Adverse Effects ${ }^{a, c, d}$ & $\begin{array}{c}\text { AWPe for 30-Day } \\
\text { Supply }\end{array}$ \\
\hline $\begin{array}{l}\text { Orlistat } \\
\text { (Xenical, Alli) }\end{array}$ & $\begin{array}{l}\text { Xenical } \\
\text { April } 1999 \\
\text { Alli } \\
\text { February } 2007\end{array}$ & $\begin{array}{l}\text { Prescription } \\
\text { OTC }\end{array}$ & Long term & $\begin{array}{l}\text { Reversible inhibitor } \\
\text { of gastrointestinal } \\
\text { lipases }\end{array}$ & $\begin{array}{l}\text { - Oily spotting flatus with discharge } \\
\text { - Fecal urgency } \\
\text { - Fatty/oily stool } \\
\text { - Oily evacuation } \\
\text { - Increased defecation } \\
\text { - Fecal incontinence }\end{array}$ & $\begin{array}{l}\text { Xenical } \$ 395.00 \\
\text { Alli } \$ 38.34\end{array}$ \\
\hline $\begin{array}{l}\text { Phentermine } \\
\text { (Adipex-P, } \\
\text { Suprenza) }\end{array}$ & 1959 & $\begin{array}{l}\text { Prescription } \\
\text { (CIV) }\end{array}$ & Short term & $\begin{array}{l}\text { Sympathomimetic } \\
\text { amine }\end{array}$ & $\begin{array}{l}\text { - Cardiovascular } \\
\text { - Central nervous system } \\
\text { - Gastrointestinal } \\
\text { - Allergic } \\
\text { - Endocrine }\end{array}$ & $\begin{array}{l}\text { Tablet/capsule } \\
\$ 18.30 \\
\text { ODT } \$ 67.50\end{array}$ \\
\hline $\begin{array}{l}\text { Diethylpropion } \\
\text { IR (Tenuate, } \\
\text { Tandil) } \\
\text { Diethylpropion } \\
\text { ER (Tenuate } \\
\text { Dospan) }\end{array}$ & August 1959 & $\begin{array}{l}\text { Prescription } \\
\text { (CIV) }\end{array}$ & Short term & $\begin{array}{l}\text { Sympathomimetic } \\
\text { amine }\end{array}$ & $\begin{array}{l}\text { - Cardiovascular } \\
\text { - Central nervous system } \\
\text { - Gastrointestinal } \\
\text { - Allergic } \\
\text { Endocrine } \\
\text { - Hematopoietic system } \\
\text { - Miscellaneous }\end{array}$ & $\$ 25.31$ \\
\hline $\begin{array}{l}\text { Benzphetamine } \\
\text { (Didrex) }\end{array}$ & October 1960 & $\begin{array}{l}\text { Prescription } \\
\text { (CIII) }\end{array}$ & Short term & $\begin{array}{l}\text { Sympathomimetic } \\
\text { amine }\end{array}$ & $\begin{array}{l}\text { - Cardiovascular } \\
\text { - Central nervous system } \\
\text { - Gastrointestinal } \\
\text { - Allergic } \\
\text { - Endocrine }\end{array}$ & $\$ 188.37$ \\
\hline $\begin{array}{l}\text { Phentermine/ } \\
\text { topiramate } \\
\text { (Qsymia) }\end{array}$ & July 2012 & $\begin{array}{l}\text { Prescription } \\
\text { (CIV) }\end{array}$ & Long term & $\begin{array}{l}\text { Combination } \\
\text { sympathomimetic } \\
\text { amine/ } \\
\text { antiepileptic drug }\end{array}$ & $\begin{array}{l}\text { - Paraesthesia } \\
\text { - Dizziness } \\
\text { - Dysgeusia } \\
\text { - Insomnia } \\
\text { - Constipation } \\
\text { - Dry mouth }\end{array}$ & $\begin{array}{l}\$ 162.60-220.80 \\
\text { based on dose }\end{array}$ \\
\hline $\begin{array}{l}\text { Lorcaserin } \\
\text { (Belviq) }\end{array}$ & June 2012 & $\begin{array}{l}\text { Prescription } \\
\text { (CIV) }\end{array}$ & Long term & $\begin{array}{l}\text { Serotonin } 2 \mathrm{C} \\
\text { receptor agonist }\end{array}$ & $\begin{array}{l}\text { Nondiabetic patients: } \\
\text { - Headache } \\
\text { - Dizziness } \\
\text { - Fatigue } \\
\text { - Nausea } \\
\text { - Dry mouth } \\
\text { - Constipation } \\
\text { Diabetic patients: } \\
\text { - Hypoglycemia } \\
\text { - Headache } \\
\text { - Back pain } \\
\text { - Cough } \\
\text { - Fatigue } \\
\end{array}$ & $\$ 239.40^{f}$ \\
\hline $\begin{array}{l}\text { Methamphetamine } \\
\text { Hcl (Desoxyn) }\end{array}$ & December 1943 & $\begin{array}{l}\text { Prescription } \\
\text { (CII) }\end{array}$ & Short term & $\begin{array}{l}\text { Sympathomimetic } \\
\text { amine }\end{array}$ & $\begin{array}{l}\text { - Cardiovascular } \\
\text { - Central nervous system } \\
\text { - Gastrointestinal } \\
\text { - Allergic } \\
\text { - Endocrine } \\
\text { - Suppression of growth in children }\end{array}$ & $\$ 360.00$ \\
\hline $\begin{array}{l}\text { Phendimetrazine } \\
\text { (Bontril) }\end{array}$ & April 1979 & $\begin{array}{l}\text { Prescription } \\
\text { (CIII) }\end{array}$ & Short term & $\begin{array}{l}\text { Sympathomimetic } \\
\text { amine }\end{array}$ & $\begin{array}{l}\text { - Cardiovascular } \\
\text { - Central nervous system } \\
\text { - Gastrointestinal } \\
\text { - Genitourinary } \\
\end{array}$ & $\$ 14.10$ \\
\hline
\end{tabular}

aSource: Product labels with prescribing information for lorcaserin, ${ }^{43}$ benzphetamine, ${ }^{44}$ diethylproprion, ${ }^{45}$ methylphenidate, ${ }^{46}$ orlistat, $, 47,48$ phendimetrazine, ${ }^{49}$ phentermine, ${ }^{50}$ and phentermine/topiramate. ${ }^{20}$

bhort-term therapy is defined as a few weeks duration. Long-term therapy is defined as 1 year.

${ }^{c}$ Medications approved after 2007-adverse events occurred $\geq 5 \%$ during studies; medications approved before 2007_adverse events have been reported in these systems. ${ }^{20,43-50}$

${ }^{d}$ Adverse effects experienced in sympathomimetic amines include by category: Cardiovascular (primary pulmonary hypertension and/or regurgitant cardiac valvular disease, precordial pain, palpitation, echocardiogram changes, tachycardia, elevation of blood pressure, and ischemic events); Central Nervous System (overstimulation, restlessness, dizziness, insomnia, euphoria, dysphoria, tremor, headache, sweating, blurring of vision, and psychosis; Gastrointestinal (dryness of the mouth, unpleasant taste, diarrhea, onstipation, nausea, vomiting, abdominal discomfort, and other gastrointestinal disturbances); Allergic (urticaria, rash, ecchymosis, erythema); Endocrine (impotence, changes in libido, gynecomastia, menstrual upset); Hematopoietic (bone marrow depression, agranulocytcosis, and leukopenia); Miscellaneous (dysuria, dyspnea, hair loss, muscle pain, increased sweating, and polyuria); Genitourinary (urinary frequency, dysuria, and changes in libido).

eDrug cost estimates based on AWP in September 2012.41

fAWP was released in June 2013

$A W P=$ average wholesale price; $C I I, I I I, I V=$ control status; FDA =U.S. Food and Drug Administration; OTC=over the counter; ODT =oral dissolving tablet. 
Formulary Management of 2 New Agents: Lorcaserin and Phentermine/Topiramate for Weight Loss

\begin{tabular}{|c|c|c|}
\hline \multicolumn{3}{|c|}{$\begin{array}{ll}\text { TABLE } 2 \text { Weight Loss Medications } \\
\\
\text { Removed from Market Due to } \\
\text { Serious Adverse Drug Events }\end{array}$} \\
\hline Drug & $\begin{array}{c}\text { Safety } \\
\text { Concerns } 26\end{array}$ & Comments \\
\hline Aminorex & $\begin{array}{l}\text { Pulmonary } \\
\text { hypertension }\end{array}$ & $\begin{array}{l}\text { - Became available in } 1965 \\
\text { in Switzerland, Austria, and } \\
\text { Germany for OTC sale. Never } \\
\text { available in United States. }{ }^{51} \\
\text { - Withdrawn in } 1972 .{ }^{51}\end{array}$ \\
\hline $\begin{array}{l}\text { Fenfluramine and } \\
\text { dexfenfluramine }\end{array}$ & Valvulopathy & $\begin{array}{l}\text { - Higher risk found particularly in } \\
\text { combination with phentermine. }{ }^{52} \\
\text { - Discontinued in September } \\
1997.53\end{array}$ \\
\hline Phenylpropanolamine & Stroke & $\begin{array}{l}\text { - All medications with phenylpro- } \\
\text { panolamine were discontinued in } \\
\text { early } 2000 \text { s. } 54\end{array}$ \\
\hline Rimonabant & $\begin{array}{l}\text { Suicidal } \\
\text { ideation and } \\
\text { behavior }\end{array}$ & $\begin{array}{l}\text { - Never approved in the United } \\
\text { States but was approved in } \\
\text { Europe in } 2006.52 \\
\text { - EMA suspended marketing autho- } \\
\text { rizations in } 2008 \text { due to risks. }{ }^{52}\end{array}$ \\
\hline Sibutramine & $\begin{array}{l}\text { Myocardial } \\
\text { infarction } \\
\text { and stroke }\end{array}$ & $\begin{array}{l}\text { - Approved in United States in } \\
1997 \text { and Europe in } 2002.3^{3} \\
\text { - Suspended for marketing authori- } \\
\text { zation in January } 2010 \text { by EMA. }{ }^{52} \\
\text { - Withdrawn from U.S. market on } \\
\text { October } 8,2010.3^{3} \\
\text { - Its withdrawal left orlistat as the } \\
\text { only prescription drug approved } \\
\text { for the long-term treatment of } \\
\text { obesity (until 2012).52 }\end{array}$ \\
\hline
\end{tabular}

EMA = European Marketing Authority; OTC = over the counter.

dexfenfluramine was commonly referred to as Fen-Phen. ${ }^{5}$ Fenfluramine, dexfenfluramine, and sibutramine were removed from the market due to cardiovascular damage concerns. ${ }^{3,6}$ According to the Orange Book, mazindol was not discontinued due to safety or efficacy reasons. ${ }^{7}$ Rimonabant, which was the first selective CBl receptor blocker, was available in 56 countries including the European Union from 2006 to 2008. However, rimonabant was never FDA-approved due to increased risk of psychiatric adverse events. Many of these agents have demonstrated short-term weight loss of a few weeks, with patients having difficulty maintaining weight loss once treatment was discontinued. ${ }^{3}$ Hence, an opportunity exists in the marketplace for weight loss agents with long-term success rates and favorable safety profiles.

In the United States, obesity accounts for an additional $\$ 190$ billion of medical spend per year, which is equivalent to $20.6 \%$ of U.S. health care expenditures. ${ }^{8}$ Obesity rates are predicted to increase $42 \%$ by 2030 , translating to an increase of $\$ 550$ billion total health care spend in the United States between 2012 and 2030. Therefore, keeping obesity rates steady may potentially have a favorable economic impact on the health care industry. ${ }^{9}$

Lifestyle changes related to diet and exercise are effective in treating many obese and overweight individuals. The Centers for Disease Control and Prevention and American Heart Association (AHA) emphasize the importance of diet and exercise by explaining the significance of reducing calorie intake and increasing calorie expenditure. However, this approach does not work for the entire population. ${ }^{10,11}$ A systematic review found that exercise only had a modest effect on chronic disease risk factors, such as hypertension where subjects reduced their blood pressure 4.9-6.9 millimeters of mercury ( $\mathrm{mm} \mathrm{Hg}$ ), in obese individuals. However, investigators still recommend obese individuals to undertake physical activity within their capabilities. ${ }^{12}$ The limited effectiveness of diet and exercise interventions in weight management suggest other treatment modalities, such as add-on pharmacotherapy, may be required for some patients. ${ }^{4,13,14}$

Although lifestyle changes are the mainstay of weight management, guidelines do acknowledge pharmacotherapy in treating obese or overweight patients. The Practical Guide: Identification, Evaluation, and Treatment of Overweight and Obesity in Adults (2000), put forth by the National Heart, Lung, and Blood Institute (NHLBI), recommends that drug therapy may be useful for patients with a BMI $\geq 30 \mathrm{~kg} / \mathrm{m}^{2}$ with no concomitant risk factors or BMI $\geq 27 \mathrm{~kg} / \mathrm{m}^{2}$ with concomitant risk factors. NHLBI recommends that weight loss medications should only be used in conjunction with physical activity, diet, and behavioral therapy. Drug therapy is considered second line (ahead of weight loss surgery) and should be considered if a patient has not lost 1 pound per week after 6 months of lifestyle therapy. ${ }^{4}$ For management of overweight and obese patients, the Adult Treatment Panel (ATP) III Cholesterol Guidelines defer to the Clinical Guidelines on the Identification, Evaluation, and Treatment of Overweight and Obesity in Adults (1998), which recommend orlistat as an adjunct to diet and physical activity for the same target population as the 2000 NHLBI obesity guidelines. ${ }^{13}$ In June 2012, the U.S. Preventive Services Task Force updated its recommendations, stating that clinicians should offer or refer patients 18 years or older with BMI $\geq 30 \mathrm{~kg} / \mathrm{m}^{2}$ to intensive, multicomponent behavioral interventions. The task force was unable to recommend medication use, despite finding that orlistat or metformin in combination with behavioral interventions resulted in weight loss and improvement of physiologic outcomes. Due to off-label use of metformin and the lack of data regarding improvements beyond medication discontinuation, the task force was unable to make a definitive recommendation. ${ }^{14}$

The American Diabetes Association (ADA) and AHA have also established recommendations in treating obese patients. ADA recommends individualized nutrition therapy for prediabetic or diabetic patients, preferably with a registered dietician. Diabetic patients should focus on physical activity and behavioral modification, especially diet, for at least 2 years after being diagnosed. For these patients, a balanced mix of carbohydrates, fat, and protein is recommended, but the most important 


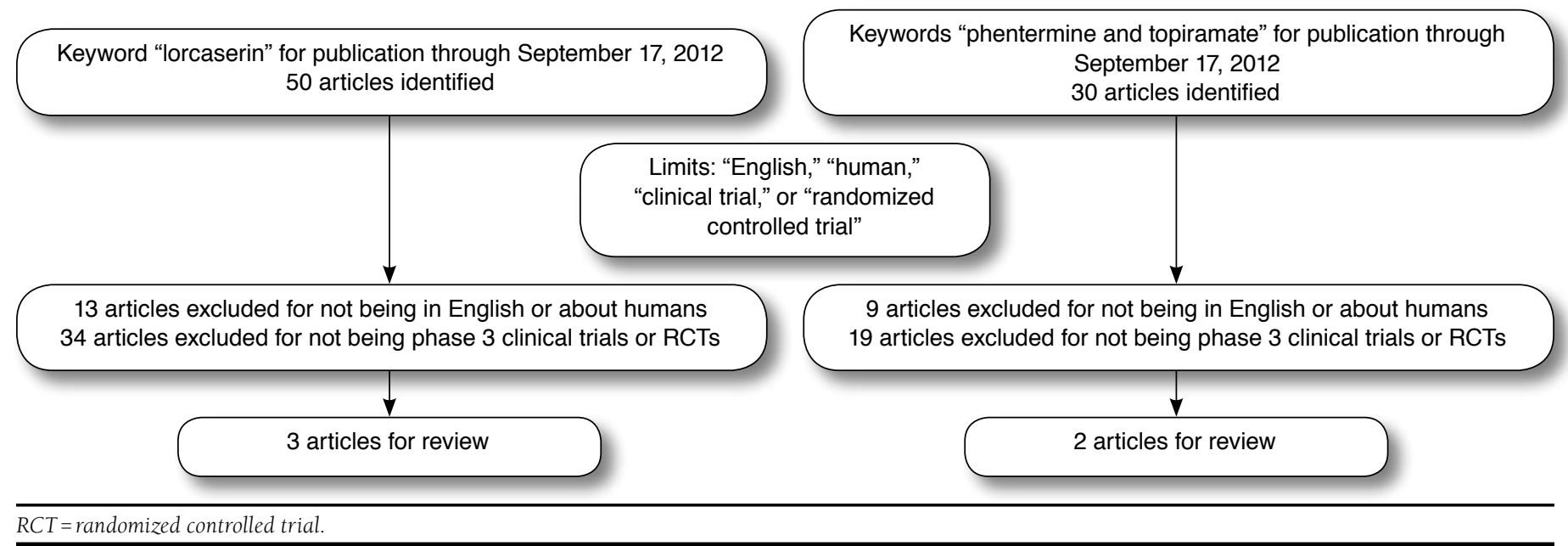

factor to consider is management of total caloric intake per day. ${ }^{15}$ Weight loss medications are not included in the ADA recommendations. The AHA guidelines are similar with no specific guidance on medications. ${ }^{11}$

Lorcaserin and phentermine/topiramate were approved by the FDA in June 2012 and July 2012, respectively. Both drugs are indicated as an adjunct to diet and exercise for chronic weight management of obese (BMI $\geq 30 \mathrm{~kg} / \mathrm{m}^{2}$ ) or overweight (BMI $\geq 27 \mathrm{~kg} / \mathrm{m}^{2}$ ) individuals with hypertension, dyslipidemia, or T2DM. Prior to June 2012, the most recent prescription obesity drug to be approved was orlistat (Xenical) in 1999. In 2007, Alli was approved, which is an over-the-counter product containing orlistat. The approval of lorcaserin and phentermine/topiramate introduces new therapeutic options in the management of obesity.

The purpose of this article is to review the clinical data of lorcaserin and phentermine/topiramate and offer insight to managed care decision makers by examining the potential impact of these medications on the U.S. health care system related to hypertension, dyslipidemia, and T2DM disease management.

\section{Methods}

A MEDLINE review was performed for articles published and available through September 17, 2012, using keywords "lorcaserin" and "phentermine and topiramate" with an emphasis on published randomized controlled trials (Figure 1). The literature search was limited to randomized controlled trials in humans published in the English language. Additional information on lorcaserin was obtained from its FDA review on the FDA website.

\section{Results}

Based on the results of the Medline review, 5 pivotal phase 3 trials were identified: 3 for lorcaserin and 2 for phentermine/ topiramate. Both agents demonstrated a statistically significant higher proportion of individuals who lost $\geq 5 \%$ of body weight, as well as higher mean weight loss when compared with placebo. Safety concerns for lorcaserin include cardiac valvulopathy and increased risk of psychiatric, cognitive, and serotonergic adverse effects. Teratogenicity and increased heart rate are major safety concerns regarding phentermine/topiramate.

\section{Pharmacokinetics}

Lorcaserin. Lorcaserin is highly bioavailable with $90 \%$ of its 10 milligram (mg) twice daily recommended dose absorbed..$^{16,17}$ The time to maximum concentration $\left(T_{\max }\right)$ of lorcaserin is approximately 2 hours. A high fat meal delays the $T_{\max }$ by $1-2$ hours, but maximum concentration $\left(C_{\max }\right)$ and area under the curve (AUC) remain unchanged. Therefore, lorcaserin can be taken with or without food. The half-life $\left(t_{1 / 2}\right)$ of lorcaserin is approximately 11 hours. Lorcaserin undergoes extensive metabolism in the liver by multiple enzymatic pathways, with the 2 major metabolites, N-sulfonate-lorcaserin (M1) and $\mathrm{N}$-carbamoyl glucuronide (M5), being inactive. ${ }^{16}$ As a mild to moderate inhibitor of CYP 2D6, lorcaserin has potential drug interactions with substrates such as dextromethorphan and desipramine, which should be monitored. Lorcaserin is $75 \%$ protein-bound with major route of elimination through the urine $(92.2 \%){ }^{17}$

When studied in clinical trials, subjects with renal dysfunction did not have a significantly altered $C_{\max }$ or AUC. Lorcaserin was studied in subjects with mild-moderate hepatic 
Formulary Management of 2 New Agents: Lorcaserin and Phentermine/Topiramate for Weight Loss

\section{TABLE 3A}

Efficacy and Safety Results from Phase 3 Trials of Lorcaserin: BLOOM

Study/Drug Regimens BLOOM $^{21}$

Lorcaserin $10 \mathrm{mg}$ twice daily or placebo twice daily for 2 years

All patients were standardized to a lifestyle modification program.

\begin{tabular}{|c|c|c|c|c|}
\hline Design/Sample & \multicolumn{4}{|c|}{ Results } \\
\hline \multirow{9}{*}{$\begin{array}{l}\text { Phase } 3 \text {, double-blind, randomized, } \\
\text { placebo-controlled trial } \\
\text { Inclusion criteria } \\
\text { - Age } 18-65 \text { years } \\
\text { - BMI } 30-45 \mathrm{~kg} / \mathrm{m}^{2} \text { or } 27-45 \mathrm{~kg} / \mathrm{m}^{2} \\
\text { with } \geq 1 \text { coexisting condition (hyper- } \\
\text { tension, dyslipidemia, cardiovascular } \\
\text { disease, impaired glucose tolerance, } \\
\text { or sleep apnea) } \\
\text { Exclusion criteria } \\
\text { - Moderate or more severe mitral } \\
\text { regurgitation } \\
\text { - Mild or more severe aortic regurgita- } \\
\text { tion }\end{array}$} & \multicolumn{4}{|l|}{ Primary endpoints } \\
\hline & & $\begin{array}{l}\text { Lorcaserin } 10 \mathrm{Mg} \\
\text { Twice Daily }\end{array}$ & $\begin{array}{l}\text { Placebo Twice } \\
\text { Daily }\end{array}$ & $P$ Value \\
\hline & $\mathrm{n}^{\mathrm{a}}$ & 1,538 & 1,499 & \\
\hline & $\%$ loss $\geq 5 \%$ weight in year 1 & 47.5 & 20.3 & $<0.001$ \\
\hline & Weight change $(\mathrm{kg})$ in year $1^{\mathrm{b}}$ & $-5.8 \pm 0.2$ & $-2.2 \pm 0.1$ & $<0.001$ \\
\hline & $\%$ loss $\geq 10 \%$ weight in year 1 & 22.6 & 7.7 & $<0.001$ \\
\hline & & $\begin{array}{c}\text { Lorcaserin Both } \\
\text { Years }\end{array}$ & $\begin{array}{c}\text { Lorcaserin Year } \\
1 \text { Then Placebo } \\
\text { Year } 2\end{array}$ & $P$ Value \\
\hline & $\mathrm{n}^{\mathrm{a}}$ & 564 & 275 & \\
\hline & $\begin{array}{l}\% \text { maintained loss } \geq 5 \% \text { weight } \\
\text { from year } 1 \text { in year } 2\end{array}$ & 67.9 & 50.3 & $<0.001$ \\
\hline
\end{tabular}

- Diabetes mellitus

- Systolic blood pressure > 140 mm Hg

- Diastolic blood pressure $>90 \mathrm{~mm} \mathrm{Hg}$

- Depression or other major psychiat-

ric disease $\leq 2$ years before randomization that necessitated treatment

with prescription medication

- Pregnancy

- Lactation

Baseline characteristics

- Race: $~ 67 \%$ White, $18 \%$ Black,

11.4\% Hispanic

- Mean age: 44 years

- Sex: 82.9\% Female

- Mean weight: $\sim 100 \mathrm{~kg}$
Safety endpoints

\begin{tabular}{|l|c|c|c|}
\hline & $\begin{array}{c}\text { Lorcaserin 10 Mg } \\
\text { Twice Daily }\end{array}$ & $\begin{array}{c}\text { Placebo Twice } \\
\text { Daily }\end{array}$ & P Value \\
\hline $\mathrm{n}$ & 1,593 & 1,584 & \\
\hline$\%$ FDVc,d & 2.7 & 2.3 & 0.70 \\
\hline$\%$ FDVc,e & 2.6 & 2.7 & \\
\hline
\end{tabular}

Note: Most common adverse events ( $\geq 5 \%$ incidence): upper respiratory infections, headache, dizziness, nasopharyngitis, nausea.

a Number analyzed using Modified Intent to Treat (MITT) analysis.

${ }^{b}$ Values are means \pm standard error (SE)

${ }^{c}$ Aortic regurgitation of greater than trace/trivial/minimal severity and/or mitral regurgitation of greater than mild severity as documented by echocardiography.

dProportion of those who developed FDV at end of year 1.

eproportion of those who developed FDV at end of year 2.

BMI = body mass index; FDV =U.S. Food and Drug Administration defined valvulopathy; $\mathrm{kg} /$ $m^{2}=$ kilogram per square meter; $m g=$ milligram; $m m \mathrm{Hg}=$ millimeter of mercury. impairment and was associated with lower $\mathrm{C}_{\max }$, higher AUC, and increased $t_{1 / 2}$ of 5-9 hours. However, no dosage adjustment is recommended for renal or hepatic dysfunction. ${ }^{16,17}$

Phentermine/topiramate. Phentermine/topiramate is a oncedaily extended-release capsule combining 2 separate drugs with different pharmacokinetics. Combining the 2 drugs into 1 formulation provides an immediate release of phentermine and delayed release of topiramate, which theoretically provides better appetite suppression throughout the day. Together, the combination results in a 7 -hour delay of topiramate peak concentration and an overall 29\% lower $C_{\max }$ of phentermine. The plasma concentrations of phentermine/topiramate increase approximately proportional to the dose. ${ }^{18}$

The pharmacokinetics for phentermine are approximately dose proportional from the low dose (3.75 $\mathrm{mg} / 23 \mathrm{mg}$ ) to high dose (15 mg/92 mg). After oral administration with the maximum dose (15 mg/92 $\mathrm{mg}$ ) $\mathrm{C}_{\max }$ is 49.1 nanograms per milliliter (ng/mL) with a $\mathrm{T}_{\max }$ of 6 hours. A high fat meal does not affect phentermine pharmacokinetics. Phentermine is $17.5 \%$ plasma-protein bound with an estimated volume of distribution $\left(\mathrm{V}_{\mathrm{d}}\right)$ of 348 liters (L). Phentermine has 2 metabolic pathways, p-hydroxylation and $\mathrm{N}$-oxidation. Cytochrome P450 3A4 enzyme primarily metabolizes phentermine, but not extensively, resulting in little impact on drug-drug interactions. Approximately 70\%-80\% of a dose exists as unchanged phentermine in urine when administered alone. The terminal half-life of phentermine is approximately 20 hours. ${ }^{19}$

The pharmacokinetics for topiramate are also approximately dose proportional from the low dose $(3.75 \mathrm{mg} / 23 \mathrm{mg})$ to high dose (15 mg/92 mg). After oral administration with the maximum dose, $C_{\max }$ is $1,020 \mathrm{ng} / \mathrm{mL}$ and the $T_{\max }$ equal to 9 hours. A high fat meal does not affect topiramate pharmacokinetics. Topiramate is $15 \%-41 \%$ plasma-protein bound. Although not extensively metabolized, topiramate has 6 metabolites via hydroxylation, hydrolysis, and glucuronidation that do not constitute more than 5\% of the administered dose. About $70 \%$ of a dose exists as unchanged topiramate in urine when 
Formulary Management of 2 New Agents: Lorcaserin and Phentermine/Topiramate for Weight Loss

\section{TABLE 3B Efficacy and Safety Results from Phase 3 Trials of Lorcaserin: BLOSSOM}

Study/Drug Regimens $\mathrm{BLOSSOM}^{22}$

Lorcaserin $10 \mathrm{mg}$ twice daily, lorcaserin $10 \mathrm{mg}$ once daily, or placebo for 52 weeks

All patients were standardized to a lifestyle modification program

Phase 3, double-blind, randomized,

placebo-controlled, parallel-group trial

Inclusion criteria

- 18-65 years old

- BMI of $30-45 \mathrm{~kg} / \mathrm{m}^{2}$ or $27-29.9 \mathrm{~kg} /$ $\mathrm{m}^{2}$ with $>1$ coexisting condition (hypertension, dyslipidemia, cardiovascular disease, impaired glucose tolerance, or sleep apnea)

- Ability to participate in a moderateintensity exercise program

Exclusion criteria

- Recent cardiovascular events, major surgeries, or medical conditions that would preclude participation in a nutritional and physical exercise program

- Diabetes mellitus

- Systolic blood pressure $\geq 150 \mathrm{~mm} \mathrm{Hg}$ or diastolic blood pressure $\geq 95$

$\mathrm{mm} \mathrm{Hg}$

- Triglycerides > $499 \mathrm{mg} / \mathrm{dl}$

- Use of SSRI in past year

- Previous bariatric surgery

- Recent use of weight loss drugs (within 1 month for over-the-counter agents, 3 months for prescription drugs)

- Very low calorie diet

- Change in weight of $\geq 5 \mathrm{~kg}$ within 3 months

Baseline characteristics

- Race: $\sim 67 \%$ White, $\sim 19 \%$ Black, $\sim 10 \%$ Hispanic

- Mean age: 44 years

- Sex: $79.8 \%$ Female

- Mean weight: $\sim 100 \mathrm{~kg}$

\section{Results}

Primary endpoints
\begin{tabular}{|l|c|c|c|c|}
\hline & $\begin{array}{c}\text { Lorcaserin } \\
10 \mathrm{Mg} \\
\text { Twice Daily }\end{array}$ & $\begin{array}{c}\text { Lorcaserin } \\
10 \mathrm{Mg} \\
\text { Once Daily }\end{array}$ & Placebo & $\boldsymbol{P}$ Value \\
\hline $\mathrm{n}^{\mathrm{a}}$ & 1,561 & 771 & 1,541 & \\
\hline$\%$ lost $\geq 5 \%$ weight & 47.2 & 40.2 & 25.0 & $<0.001$ \\
\hline $\begin{array}{l}\text { Least squares mean } \\
\text { weight loss (95\% CI) }\end{array}$ & $5.8 \%(5.5-6.2)$ & $4.7 \%(4.3-5.2)$ & $2.8 \%(2.5-3.2)$ & $<0.001$ \\
\hline$\%$ lost $\geq 10 \%$ weight & 22.6 & 17.4 & 9.7 & $<0.001$ \\
\hline
\end{tabular}

Safety endpoints

\begin{tabular}{|l|c|c|c|}
\hline & $\begin{array}{c}\text { Lorcaserin 10 Mg } \\
\text { Twice Daily }\end{array}$ & $\begin{array}{c}\text { Lorcaserin 10 Mg } \\
\text { Once Daily }\end{array}$ & Placebo \\
\hline $\mathrm{n}^{\mathrm{a}}$ & 1,208 & 622 & 1,153 \\
\hline$\% \mathrm{FDV}(95 \% \mathrm{CI})^{\mathrm{b}, \mathrm{c}}$ & $2.0 \%(1.2-2.8)$ & $1.4 \%(0.5-2.4)$ & $2.0 \%(1.2-2.8)$ \\
\hline
\end{tabular}

Note: Most common adverse events ( $\geq 5 \%$ incidence): headache, upper respiratory infection, nausea, dizziness, and fatigue.

${ }^{a}$ Number analyzed using Modified Intent to Treat (MITT) analysis.

${ }^{b}$ Aortic regurgitation of greater than trace/trivial/minimal severity and/or mitral regurgitation of greater than mild severity as documented by echocardiography.

cProportion of patients that developed FDV from baseline.

$B M I=$ body mass index; $C I=$ confidence interval; $F D V=U . S$. Food and Drug Administration defined valvulopathy; $\mathrm{kg} / \mathrm{m}^{2}=$ kilogram per square meter; $\mathrm{mg}=$ milligram; $\mathrm{mg} / \mathrm{dl}=$ milligram per deciliter; $\mathrm{mm} \mathrm{Hg}=$ millimeter of mercury; SSRI= selective serotonin reuptake inhibitor. administered alone. The terminal half-life is approximately 65 hours. ${ }^{19}$ Due to plasma levels of topiramate increasing, dose adjustment is recommended in patients with moderate or severe renal or hepatic impairment no greater than phentermine $7.5 \mathrm{mg} /$ topiramate $46 \mathrm{mg} .18,20$

\section{Efficacy and Safety}

Lorcaserin. The efficacy and safety of lorcaserin was studied in three phase 3 pivotal trials: Multicenter, Placebo-Controlled Trial of Lorcaserin for Weight Management (BLOOM); ${ }^{21}$ the BLOSSOM trial (BLOSSOM), a 1-year randomized trial of lorcaserin for weight loss in obese and overweight adults; ${ }^{22}$ and the BLOOM-DM study (BLOOM-DM), a randomized placebocontrolled clinical trial of lorcaserin for weight loss in T2DM. ${ }^{23}$ The study designs, samples, efficacy, and safety outcomes are shown in Table 3A-C.

Overall, all 3 phase III clinical studies showed that the percentage of patients with $\geq 5 \%$ body weight reduction and percentage of body weight change when using lorcaserin $10 \mathrm{mg}$ daily versus placebo were statistically significant. Lack of clinical significance (patients only lost an average 4 to 8 pounds) and meeting FDA guidance efficacy benchmarks for weight management products makes the efficacy and clinical utility of these medications questionable. FDA benchmarks include the following: (a) difference in mean weight loss must be $\geq 5 \%$ than placebo and statistically significant, and (b) proportion of patients who lose $\geq 5 \%$ in active group is $\geq 35 \%$, and approximately twice the placebo group, with the difference being statistically significant. ${ }^{24}$ Lorcaserin did not meet the difference in mean weight loss of $\geq 5 \%$ versus placebo. Also of concern is the high drop-out rate within the studies (33\%-49\%). There are no head-to-head trials with other medications used for weight loss. ${ }^{21-23}$

Both lorcaserin and phentermine/topiramate were previously rejected by the FDA due to safety concerns. Mammary and brain tumors occurred at a higher incidence in rats treated 


\section{TABLE 3C}

$\mathrm{BLOOM}^{-\mathrm{DM}^{23}}$

Lorcaserin $10 \mathrm{mg}$ twice daily, lorcaserin $10 \mathrm{mg}$ once daily, or placebo for 52 weeks

All patients were standardized to a lifestyle modification program

Efficacy and Safety Results from Phase 3 Trials of Lorcaserin: BLOOM-DM

Phase 3, double-blind, randomized,

placebo-controlled trial

Inclusion criteria

- Had T2DM treated with metformin, sulfonylurea, or both

- HbAlc of $7 \%-10 \%$

- 18-65 years old

- BMI $27-45 \mathrm{~kg} / \mathrm{m}^{2}$

- Able to participate in moderate intensity exercise program

Exclusion criteria

- Use of insulin in any form

- Use of exenatide or pramlinitide

- Prior bariatric surgery

- Change in weight of $\geq 5 \mathrm{~kg}$ within 3 months

- Binge Eating Scale (16) score > 17

- Significant change in cigarette smoking within 3 months

- Malignancy within 5 years

- Recent major surgery

- History of seizure disorder within

5 years

- Depression or other major psychiatric disease requiring treatment with prescription medication within 1 year.

- Beck Depression Inventory II (BDI-II) Score of $\geq 20$ or individual response with suicidal thoughts

- Pregnancy or lactation

- Cardiopulmonary exclusions: history of cardiac valve disease or pulmonary artery hypertension, myocardial infarction, or stroke within 6 months, or unstable angina

- Medication exclusions: prior administration of lorcaserin or drugs associated with cardiac valvulopathy, use of SSRIs or SNRIs, topiramate, and drugs for weight loss

- Lab exclusions: TSH and/or T4 abnormalities, triglycerides $>499$ $\mathrm{mg} / \mathrm{dl}, \mathrm{LDL} \geq 160 \mathrm{mg} / \mathrm{dl}$, AST or ALT $>2.5$ times $(\mathrm{x})$ ULN, bilirubin $>1.5 \mathrm{x}$ ULN, creatinine $>1.5 \mathrm{x}$ ULN, positive HIV, Hep B, or Hep C screen

Baseline characteristics

- Race: $60 \%$ White, $21 \%$ Black,

$\sim 14 \%$ Hispanic.

- Mean age: $~ 53$ years

- Sex: 54\% Female

- Mean weight: $103 \mathrm{~kg}$

- On metformin: 91\%

- On sulfonylurea: $50 \%$

- On both: $40 \%$

Primary endpoints
\begin{tabular}{|l|c|c|c|c|}
\hline & $\begin{array}{c}\text { Lorcaserin } \\
10 \mathrm{Mg} \\
\text { Twice Daily }\end{array}$ & $\begin{array}{c}\text { Lorcaserin } \\
10 \mathrm{Mg} \\
\text { Once Daily }\end{array}$ & Placebo & $P$ Value \\
\hline $\mathrm{n}^{\mathrm{a}}$ & 251 & 95 & 248 & \\
\hline$\%$ lost $\geq 5 \%$ weight & 37.5 & 44.7 & 16.1 & $<0.001$ \\
\hline $\begin{array}{l}\text { Least squares mean \% } \\
\text { weight change (+/-SEM) }\end{array}$ & $-4.5+/-0.4$ & $-5.0+/-0.5$ & $-1.5+/-0.4$ & $<0.001$ \\
\hline$\%$ lost $\geq 10 \%$ weight & 16.3 & 18.1 & 4.4 & $<0.001$ \\
\hline
\end{tabular}

Glycemic parameters

\begin{tabular}{|l|c|c|c|}
\hline & $\begin{array}{c}\text { Lorcaserin } \\
\text { 10 Mg Twice Daily }\end{array}$ & $\begin{array}{c}\text { Lorcaserin } \\
\text { 10 Mg Once Daily }\end{array}$ & Placebo \\
\hline $\mathrm{n}^{\mathrm{a}}$ & 251 & 93 & 248 \\
\hline Change in FPG $(\mathrm{mg} / \mathrm{dl})$ & $-27.4 \pm 2.5$ & $-28.4 \pm 3.8$ & $-11.9 \pm 2.5$ \\
& $(P<0.001)$ & $(P=0.015)$ & \\
\hline HbAlc \% change & $-0.9 \pm 0.06$ & $-1.0 \pm 0.09$ & $-0.4 \pm 0.06$ \\
& $(P<0.001)$ & $(P<0.001)$ & \\
\hline
\end{tabular}

Safety endpoints

\begin{tabular}{|l|c|c|c|}
\hline & $\begin{array}{c}\text { Lorcaserin 10 Mg } \\
\text { Twice Daily }\end{array}$ & $\begin{array}{c}\text { Lorcaserin 10 Mg } \\
\text { Once Daily }\end{array}$ & Placebo \\
\hline $\mathrm{n}$ & 207 & 80 & 200 \\
\hline FDV $(\%)^{\mathrm{b}, \mathrm{c}}$ & $2.9 \%(P=0.122)$ & $2.5 \%(P=0.187)$ & $0.5 \%$ \\
\hline
\end{tabular}

Note: Most common adverse events ( $\geq 5 \%$ incidence): headache, back pain, nasopharyngitis, and nausea.

${ }^{a}$ Number analyzed using Modified Intent to Treat (MITT) analysis.

${ }^{b}$ Aortic regurgitation of greater than trace/trivial/minimal severity and/or mitral regurgitation of greater than mild severity as documented by echocardiography.

cPercentage of patients at week 52 with FDV not present at baseline.

$A S T=$ aspartate aminotransferase; $A L T=$ alanine aminotransferase; $B M I=$ body mass index; HbAlc = hemoglobin Alc; FPG = fasting plasma glucose; FDV =U.S. Food and Drug Administration defined valvulopathy; Hep $B=$ hepatitis B; Hep $C=$ hepatitis $C$; HIV = human immunodeficiency virus; $\mathrm{kg} / \mathrm{m}^{2}=$ kilogram per square meter; $L D L=$ low-density lipoprotein; $\mathrm{mg} / \mathrm{dl}=$ milligram per deciliter; SNRI = selective norepinephrine reuptake inhibitor; SEM = standard error of the mean; SSRI = selective serotonin reuptake inhibitor; T2DM = type 2 diabetes mellitus; TSH = thyroid-stimulating hormone; ULN = upper limit of normal. with lorcaserin in carcinogenicity studies. However, when mammary tumor data were re-evaluated, fewer tumors were categorized as malignant compared with the original drug application. Regarding brain tumors, a clinical study determined that only a small proportion of lorcaserin enters the central nervous system. ${ }^{25}$ The original drug application for lorcaserin also showed a higher frequency of FDA-defined valvulopathy (mild or greater aortic regurgitation and/or moderate or greater mitral regurgitation) in subjects..$^{23}$ However, in vitro receptor assays demonstrated that lorcaserin is more selective 
Formulary Management of 2 New Agents: Lorcaserin and Phentermine/Topiramate for Weight Loss

\section{TABLE 4A}

Efficacy and Safety Results from Phase 3 Trials of Phentermine/Topiramate: CONOUER

Study/Drug Regimens CONQUER $^{27}$

Phentermine $7.5 \mathrm{mg} /$ topiramate $46 \mathrm{mg}$ daily, phentermine $15 \mathrm{mg} /$ topiramate $92 \mathrm{mg}$ daily, or placebo daily for 56 weeks

All patients were standardized to a lifestyle modification program

\begin{tabular}{|c|c|c|c|c|c|}
\hline Design/Sample & \multicolumn{5}{|c|}{ Results } \\
\hline \multirow{5}{*}{$\begin{array}{l}\text { Phase } 3 \text {, double-blind, randomized, } \\
\text { placebo-controlled trial } \\
\text { Inclusion criteria } \\
\text { - } 18-70 \text { years old } \\
\text { - BMI } 27-45 \mathrm{~kg} / \mathrm{m}^{2} \\
\text { - } \geq 2 \text { of following comorbidities: } \\
\text { - Systolic blood pressure } 140-160 \mathrm{~mm} \\
\text { Hg (130-160 mm Hg in diabetes) } \\
\text { - Diastolic blood pressure } 90-100 \mathrm{~mm} \\
\text { Hg ( } 85-100 \mathrm{~mm} \text { Hg in diabetes), or } \\
\text { taking }>2 \text { antihypertensive drugs }\end{array}$} & \multicolumn{5}{|c|}{ Primary endpoints } \\
\hline & & $\begin{array}{c}\text { Phentermine } 7.5 \mathrm{Mg} / \\
\text { Topiramate } 46 \mathrm{Mg}\end{array}$ & $\begin{array}{c}\text { Phentermine } 15 \mathrm{Mg} / \\
\text { Topiramate } 92 \mathrm{Mg}\end{array}$ & Placebo & $\begin{array}{c}P \\
\text { Value }\end{array}$ \\
\hline & $\mathrm{n}^{\mathrm{a}}$ & 488 & 981 & 979 & \\
\hline & $\begin{array}{l}\% \text { lost } \geq 5 \% \\
\text { weight }\end{array}$ & 62 & 70 & 21 & $<0.001$ \\
\hline & $\begin{array}{l}\text { Least squares } \\
\text { mean \% change } \\
\text { in weight } \\
(95 \% \mathrm{CI})\end{array}$ & $-7.8(-8.5 \%$ to $-7.1 \%)$ & $-9.8(-10.4 \%$ to $-9.3 \%)$ & $\begin{array}{c}-1.2 \\
(-1.8 \% \text { to } \\
-0.7 \%)\end{array}$ & $<0.001$ \\
\hline
\end{tabular}

antihypertensive drugs

- Triglycerides (TG) 2.26-4.52 mmol/L

or using $\geq 2$ lipid-lowering drugs

- Fasting blood glucose $(B G)>5.55$ $\mathrm{mmol} / \mathrm{L}, \mathrm{BG}>7.77 \mathrm{mmol} / \mathrm{L}$ at 2

hours after oral glucose load during oral glucose tolerance test, or diagnosed T2DM managed with lifestyle changes or metformin monotherapy

- Waist circumference $\geq 102 \mathrm{~cm}$ for men or $\geq 88 \mathrm{~cm}$ for women

Exclusion criteria

- Blood pressure > 160/100 mm Hg

- Fasting BG > $13.32 \mathrm{mmol} / \mathrm{L}$

- TG > $4.52 \mathrm{mmol} / \mathrm{L}$ at randomization

- Type 1 diabetes

- Other antidiabetic agents besides metformin

- History of nephrolithiasis

- Recurrent major depression

- Presence or history of suicidal behavior or ideation with intent to act

- PHQ-9 $\geq 10$ (substantial depression symptoms) ${ }^{c}$

- Antidepressant drugs (but not tricyclic antidepressant drugs or monoamine oxidase inhibitors) if dose was not stable for 3 months

Baseline characteristics

- Race: $~ 86 \%$ White, $~ 11 \%$ Black, $~ 7 \%$ Hispanic

- Mean age: $~ 51$ years

- Sex: $70 \%$ Female

- Mean weight: $\sim 103 \mathrm{~kg}$
Safety endpoints

\begin{tabular}{|c|c|c|c|}
\hline & $\begin{array}{c}\text { Phentermine } 7.5 \mathrm{Mg} / \\
\text { Topiramate } 46 \mathrm{Mg}\end{array}$ & $\begin{array}{c}\text { Phentermine } 15 \mathrm{Mg} / \\
\text { Topiramate } 92 \mathrm{Mg}\end{array}$ & Placebo \\
\hline $\mathrm{n}^{\mathrm{a}}$ & 498 & 994 & 993 \\
\hline $\begin{array}{l}\text { Average increase } \\
\text { in } \mathrm{HR}(\mathrm{bpm})^{\mathrm{b}}\end{array}$ & $\begin{array}{c}0.1 \\
(-1.0 \text { to } 1.1 ; 0.92)\end{array}$ & $\begin{array}{c}1.7 \\
(0.9 \text { to } 2.4 ;<0.001)\end{array}$ & $\begin{array}{c}-0.1 \\
(-0.9 \text { to } 0.8 ; 0.90)\end{array}$ \\
\hline $\begin{array}{l}\text { Endpoint change } \\
\text { meanc }^{c}(95 \% \mathrm{CI})\end{array}$ & $\begin{array}{c}-1.4 \\
(-1.7 \text { to }-1.1)\end{array}$ & $\begin{array}{c}-1.3 \\
(-1.5 \text { to }-1.1)\end{array}$ & $\begin{array}{c}-1.0 \\
(-1.2 \text { to }-0.8)\end{array}$ \\
\hline $\begin{array}{l}\text { Actual suicidal } \\
\text { attempt }^{\mathrm{d}}\end{array}$ & 0 & 0 & 0 \\
\hline Suicidalityd & $<1 \%$ & $<1 \%$ & $<1 \%(P=0.957)$ \\
\hline
\end{tabular}

\begin{tabular}{|l|c|c|c|}
\hline & $\begin{array}{c}\text { Phentermine 7.5mg/ } \\
\text { Topiramate 46mg }\end{array}$ & $\begin{array}{c}\text { Phentermine 15mg/ } \\
\text { Topiramate 92 mg }\end{array}$ & Placebo \\
\hline $\mathrm{n}$ & 27 & 60 & 42 \\
\hline $\begin{array}{l}\text { Fat mass change } \\
\text { mean (kg) }\end{array}$ & $-7.0(P<0.001)$ & $-8.1(P<0.001)$ & $3.8 \%$ \\
\hline
\end{tabular}

Note: Most common adverse events ( $\geq 5 \%$ incidence): dry mouth, paraesthesias, constipation, insomnia, dizziness, dysgeusia.

a Number analyzed using Modified Intent to Treat (MITT) analysis.

b(95\% confidence interval; $P$ value).

cPHQ-9 = Patient Health Questionaire-9 self-administered mental health examination. ${ }^{d}$ C-SSRS = Columbia Suicide Severity Rating Scale.

$B M I=$ body mass index; $b p m=$ beats per minute; $C I=$ confidence interval; $\mathrm{cm}=$ centimeter; $H R=$ heart rate; $m m$ HG = millimeter of mercury; $\mathrm{kg} / \mathrm{m}^{2}=$ kilogram per square meter; $\mathrm{mmol} / \mathrm{L}=$ millimoles per liter; T2DM = type 2 diabetes mellitus. for the 5-HT2C receptor and not 5-HT2B receptor, which is the receptor associated with valvulopathy. ${ }^{26}$ These findings diminished the initial safety concerns, therefore, supporting a favorable benefit-risk profile for lorcaserin to gain FDA approval.

Phentermine/topiramate. The efficacy and safety of phentermine/topiramate was studied in two phase 3 pivotal trials: (1) effects of low-dose, controlled-release phentermine plus topiramate combination on weight and associated comorbidities in overweight and obese adults (CONQUER), a randomized, placebo-controlled phase 3 trial, ${ }^{27}$ and (2) controlled-release phentermine/topiramate in severely obese adults, a randomized controlled trial (EQUIP). ${ }^{28}$ The study designs, samples, efficacy, and safety outcomes are shown in Table 4A and 4B.

Phentermine/topiramate was approved with statistically significant results that met FDA weight guidance efficacy benchmarks. The clinical significance of phentermine/topiramate is questionable with approximately an 8- to 21-pound average weight loss in the 2 clinical trials. Additionally, high drop-out rates were seen with phentermine/topiramate (up to $46 \%$ ). ${ }^{27-28}$

Teratogenicity (orofacial cleft) and elevations in resting heart rate are safety concerns for phentermine/topiramate. Consequently, a risk evaluation and mitigation strategy (REMS) 
Formulary Management of 2 New Agents: Lorcaserin and Phentermine/Topiramate for Weight Loss

\section{TABLE 4B Efficacy and Safety Results from Phase 3 Trials of Phentermine/Topiramate: EOUIP}

Study/Drug Regimens EQUIP28

Phentermine $3.75 \mathrm{mg} /$ topiramate $23 \mathrm{mg}$ daily, phentermine $15 \mathrm{mg} / \mathrm{topi}$ ramate $92 \mathrm{mg}$ daily, or placebo daily for 56 week

All patients were standardized to a lifestyle modifica tion program

\section{Design/Sample}

Phase 3, multicentered, double-

blinded, parallel-group, randomized,

placebo-controlled trial

Inclusion criteria

- 18-70 years old

- $\mathrm{BMI} \geq 35 \mathrm{~kg} / \mathrm{m}^{2}$

- Triglycerides $\leq 200 \mathrm{mg} / \mathrm{dl}$ with treatment of 0-1 lipid-lowering medication

- Blood pressure $\leq 140 / 90 \mathrm{~mm} \mathrm{Hg}$ with treatment of 0-2 antihypertensive medications

- Fasting serum glucose level $\leq 110$ $\mathrm{mg} / \mathrm{dl}$

Exclusion criteria

- Weight gain or loss $>5 \mathrm{~kg}$ within past 3 months

- History of eating disorders, previous bariatric surgery, glaucoma, and nephrolithiasis

- Thyroid dysfunction

- Chronic systemic glucocorticoid therapy

- Bipolar disorder or psychosis history, $>1$ lifetime episode of major depression, current depression of moderate or greater severity, presence or history of suicidal behavior or ideation with some intent to act, or antidepressant use that had not been stable for at least 3 months

- Stroke, myocardial infarction, lifethreatening arrhythmia, or coronary revascularization within past 6 months

- Unstable angina, congestive heart failure, or known or suspected clinically significant cardiac valvulopathy

- Cholelithiasis within past 6 months

- Use of any investigational medication or device within the last month

Baseline characteristics

- Race: $~ 80 \%$ White, $~ 17 \%$ Black

- Mean age: 42.7 years

- Sex: $~ 83 \%$ Female

- Mean weight: $~ 115 \mathrm{~kg}$
Results

Primary endpoints
\begin{tabular}{|l|c|c|c|c|}
\hline & $\begin{array}{c}\text { Phentermine 3.75 } \\
\text { Mg/Topiramate 23 } \\
\text { Mg Daily }\end{array}$ & $\begin{array}{c}\text { Phentermine 15 Mg/ } \\
\text { Topiramate 92 Mg } \\
\text { Daily }\end{array}$ & Placebo & $\begin{array}{c}P \\
\text { Value }\end{array}$ \\
\hline $\mathrm{n}^{\mathrm{a}}$ & 234 & 498 & 498 & \\
\hline $\begin{array}{l}\% \text { lost } \geq 5 \% \\
\text { weight }\end{array}$ & 44.9 & 66.7 & 17.3 & $<0.001$ \\
\hline $\begin{array}{l}\% \text { lost } \geq 10 \% \\
\text { weight }\end{array}$ & 18.8 & 47.2 & 7.4 & $<0.001$ \\
\hline $\begin{array}{l}\% \text { lost } \geq 15 \% \\
\text { weight }\end{array}$ & 7.3 & 32.3 & 3.4 & \\
\hline $\begin{array}{l}\text { Least squares \% } \\
\text { mean change in } \\
\text { weight } \\
(95 \% \text { CI })\end{array}$ & -5.1 & -10.92 & -1.55 & $<0.001$ \\
$(-10.2$ to -11.7) & $(-0.8$ to -2.3) & \\
\hline
\end{tabular}

Safety endpoints

\begin{tabular}{|l|c|c|c|}
\hline & $\begin{array}{c}\text { Phentermine 3.75 Mg/ } \\
\text { Topiramate } \\
\text { 23 Mg Daily }\end{array}$ & $\begin{array}{c}\text { Phentermine 15 Mg/ } \\
\text { Topiramate } \\
\text { 92 Mg Daily }\end{array}$ & Placebo \\
\hline $\begin{array}{l}\text { Average increase in HR } \\
\text { (bpm) }\end{array}$ & $\begin{array}{c}0.3 \\
(P=0.955)\end{array}$ & $\begin{array}{c}1.2 \\
(P=0.083)\end{array}$ & -0.2 \\
\hline $\begin{array}{l}\text { Change in serum } \\
\text { bicarbonate (mEq/L) }\end{array}$ & -1.6 & -1.7 & -03 \\
\hline $\begin{array}{l}\text { PHQ-9 mean (95\% CI) } \\
\text { week 56 changeb }\end{array}$ & $\begin{array}{c}-1.3 \\
(-1.6 \text { to -1.0) }\end{array}$ & $\begin{array}{c}-1.2 \\
(-1.6 \text { to }-0.8)\end{array}$ & $\begin{array}{c}-1.5 \\
(-1.8 \text { to }-1.3)\end{array}$ \\
\hline $\begin{array}{l}\mathrm{n}(\%) \text { of patients with } \\
\text { postbaseline suicidal } \\
\text { behavior }\end{array}$ & $0(0)$ & $0(0)$ & $0(0)$ \\
\hline
\end{tabular}

Note: Most common adverse events ( $\geq 5 \%$ incidence): paraesthesia, dry mouth, constipation, dysgeusia, and insomnia.

${ }^{a}$ Number analyzed using Modified Intent to Treat (MITT) analysis.

bPHQ-9 = Patient Health Questionaire-9 self-administered mental health examination.

$B M I=$ body mass index; bpm = beats per minute; $C I=$ confidence interval; $C$-SSRS $=$ Columbia Suicide Severity Rating Scale; HR= heart rate; $\mathrm{kg} / \mathrm{m}^{2}=$ kilogram per square meter; $\mathrm{mg} / \mathrm{dl}=$ milligram per deciliter; $\mathrm{mm} \mathrm{Hg}=$ millimeter of mercury. was required for phentermine/topiramate's approval to address teratogenicity. The REMS program includes a medication guide, patient brochure, and formal training program for prescribers. In October 2012, Vivus submitted a REMS amendment, which was approved in April 2013 by the FDA, permitting expansion to retail pharmacies-previously it was available only through specially certified mail order pharmacies. ${ }^{26,29,30}$ Although phentermine/topiramate was associated with increased heart rates, the FDA decided that the greater reductions in blood pressure and weight loss supported a favorable benefit-risk balance to gain approval. ${ }^{26}$

\section{Discussion}

\section{Managed Care Considerations}

The FDA has not approved a prescription obesity drug since 1999. However, 13 years later (2012) lorcaserin and phentermine/topiramate were approved within weeks of each other. A third agent, combination naltrexone/bupropion, is anticipated to gain FDA approval in 2014..$^{31}$ Despite considerable delays between obesity drug approvals by the FDA, these drugs may soon undergo a "special medical use" approval process that will allow for accelerated clinical trials and smaller groups of patients than traditionally required by the FDA. ${ }^{32}$ The "special 
medical use" approval process aligns with the U.S. government's plan to double the amount of new prescription drugs launched on the market for narrow and high-risk populations, including the morbidly obese. ${ }^{33}$

The surge of prescription obesity drugs may have a significant impact on managed care organizations. During its first week on the market, phentermine/topiramate was covered by health plans approximately a third of the time for their members, which was higher than anticipated. ${ }^{34}$ However, since then sales have been much lower than expected but are likely to increase with the expansion of distribution to retail pharmacies in 2013. ${ }^{29}$ Traditionally, weight loss agents are excluded from coverage, since they are considered lifestyle drugs. However, Express Scripts, the largest pharmacy benefit management company (PBM) in the United States, has included phentermine/topiramate on its national formulary. ${ }^{35}$ Aetna, the nation's third-largest health insurer, considers lorcaserin and phentermine/topiramate "medically necessary" when meeting certain clinical criteria. ${ }^{36}$ Express Scripts and Aetna's coverage of these medications signifies how weight loss is being considered a chronic medical condition and not simply lifestyle therapy, setting the stage for smaller PBMs and health plans to potentially follow suit. ${ }^{37}$

Both agents have been studied versus placebo in obese and overweight patients with comorbidities such as hypertension, dyslipidemia, or T2DM. Average weight loss at 1 year from baseline ranged from 3\%-3.7\% for patients taking lorcaserin, while those taking phentermine/topiramate on average lost a range of $6.7 \%$ (lowest dose) to $8.9 \%$ (recommended dose). ${ }^{38}$ The efficacy and safety of lorcaserin and phentermine/topiramate in diabetic patients were evaluated in clinical trials. ${ }^{23,25}$ Statistically significant improvements in blood pressure, cholesterol, and triglycerides were observed among diabetic patients taking phentermine/topiramate but not lorcaserin. However, in the BLOSSOM trial, more patients assigned to the lorcaserin twice daily group versus placebo decreased total daily use of medications to treat hypertension $(4.0 \%$ vs. $3.1 \%$, respectively) and dyslipidemia (2.6\% vs. $1.4 \%$, respectively). ${ }^{22}$ In the CONQUER trial, more patients had their antihypertensive drugs withdrawn in the phentermine/topiramate groups at doses of $7.5 \mathrm{mg} / 46 \mathrm{mg}(11 \%)$ and $15 \mathrm{mg} / 92 \mathrm{mg}(15 \%)$ than placebo $(5 \%){ }^{25}$ These data show potential for these new medications to positively impact comorbidities. The BLOOM-DM trial evaluating lorcaserin included diabetic patients taking metformin or a sulfonylurea only, while CONQUER only allowed for metformin use in evaluating phentermine/topiramate. Therefore, the efficacy and safety of lorcaserin or phentermine/ topiramate in conjunction with other antidiabetic medications is unknown. 23,25

\section{Drug Cost}

Approximately $42 \%$ of the population is projected to be obese by 2030 , leading to a $\$ 549.5$ billion increase in medical expen- ditures attributed to treatment of weight-related conditions such as T2DM, heart disease, stroke, sleep apnea, and cancer (endometrial, breast, colon). ${ }^{1,39}$ Furthermore, analysts project weight loss medications to produce $\$ 3.1$ billion in worldwide sales by 2016. ${ }^{40}$ Phentermine/topiramate's monthly cost of maintenance dosing ranges from $\$ 162.60$ to $\$ 220.80$ based on average wholesale price (AWP). Lorcaserin monthly therapy is $\$ 239.40$ based on AWP. ${ }^{41}$ With the introduction of new weight loss medications and weight loss being considered less as lifestyle therapy by managed care payers, spend in this therapeutic category traditionally excluded by health insurers will likely increase. $^{37}$

\section{Utilization Management}

Utilization management is essential to prevent off-label use and ensure that weight loss medications are used appropriately as part of a comprehensive treatment plan. On December 3, 2012, the 2nd U.S. Circuit Court of Appeals in New York determined that a pharmaceutical sales representative can promote "legal, off-label uses" of FDA-approved drugs as part of the freedom of speech rights under the First Amendment. ${ }^{42}$ Such decision is a milestone that provides pharmaceutical companies leverage to promote off-label use of their products.

The utilization management (prior authorization) criteria should consider the following factors: appropriate patient selection, lifestyle modifications, safety considerations, and requirements for continuation of therapy. Lorcaserin and phentermine/topiramate should only be used in patients with a BMI $\geq 30 \mathrm{~kg} / \mathrm{m}^{2}$ or BMI $\geq 27 \mathrm{~kg} / \mathrm{m}^{2}$ with concomitant risk factors (hypertension, dyslipidemia, or T2DM). In conjunction with medication, a reduced-calorie diet (500-600 kcal reduction) and increased physical activity (moderate exercise 30 minutes each day) should be included in a patient's weight loss treatment. Additional safety concerns of lorcaserin that should be considered are psychiatric, cognitive, and serotonergic adverse effects. ${ }^{26,43}$ Phentermine/topiramate is associated with increased risk of metabolic acidosis, glaucoma, and psychiatric and cognitive adverse effects. ${ }^{20,26}$ For continuation of pharmacotherapy with lorcaserin and phentermine/topiramate, weight loss response should be evaluated by week $12 .{ }^{26,44}$ If a patient taking lorcaserin does not lose $\geq 5 \%$ baseline body weight by week 12 , further benefit is unlikely and use should be discontinued. Phentermine/topiramate should be dose escalated or discontinued if a patient has not lost $\geq 3 \%$ baseline body weight with the $7.5 \mathrm{mg} / 46 \mathrm{mg}$ dose. Following dose escalation to $15 \mathrm{mg} / 92 \mathrm{mg}$ after an additional 12 weeks of treatment, weight loss should be evaluated. If weight loss of $5 \%$ from baseline is not achieved, benefit is unlikely and use should be discontinued.

The involvement of care management teams in targeting overweight and obese patients should also be considered. Nurses and/or pharmacists targeting members via telephone and encouraging adherence to a weight loss program may be 


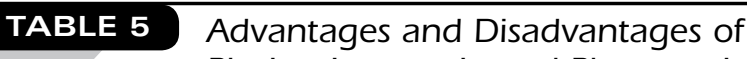
Placing Lorcaserin and Phentermine/ Topiramate on the Medical Benefit

\begin{tabular}{|c|c|}
\hline Adv & es \\
\hline $\begin{array}{l}\text { - Ensures that } \\
\text { patients are in } \\
\text { a weight reduc- } \\
\text { tion program, } \\
\text { since these pro- } \\
\text { grams will be } \\
\text { covered under } \\
\text { the medical } \\
\text { benefit as well. } \\
\text { - Encourages } \\
\text { patients to be } \\
\text { compliant with } \\
\text { their medica- } \\
\text { tion regimens. }\end{array}$ & $\begin{array}{l}\text { - The Centers for Medicare \& Medicaid Services (CMS) } \\
\text { does not assign specific J codes to drugs that will not } \\
\text { be covered, such as weight loss drugs. } \\
\text { - If CMS assigns J code, oral drugs will likely have a } \\
\text { nonclassified J code and would make monitoring of } \\
\text { utilization difficult. } \\
\text { - Utilization management is less robust on the medical } \\
\text { benefit compared with the pharmacy benefit. } \\
\text { - Drugs on the medical benefit are usually paid after } \\
\text { the drugs have already been administered unlike the } \\
\text { pharmacy benefit in which it is more customary for } \\
\text { drugs to undergo prior authorization before patients } \\
\text { receive the drugs. } \\
\text { - Member cost share can vary, with the pharmacy ben- } \\
\text { efit using a basic copay structure, while the medical } \\
\text { benefit often employs a deductible. } \\
\text { - Physician offices may not have as rigorous safety pre- } \\
\text { cautions as pharmacies in their dispensing procedures. }\end{array}$ \\
\hline
\end{tabular}

another strategy health plans can utilize in order to optimize the member's use of lorcaserin or phentermine/topiramate. This method may also improve patient safety and monitoring for side effects.

Although the majority of oral drugs may be covered under the pharmacy benefit, health insurers may consider covering lorcaserin and phentermine/topiramate under the member's medical benefit. Aetna covers lorcaserin and phentermine/ topiramate under the medical benefit for patients who "failed to lose at least one pound per week after at least 6 months on a weight loss regimen that includes a low calorie diet, increased physical activity, behavioral therapy, and who meet either of the following selection criteria": BMI $\geq 30 \mathrm{~kg} / \mathrm{m}^{2}$ or BMI $\geq 27$ $\mathrm{kg} / \mathrm{m}^{2}$ with obesity-related risk factors (coronary heart disease, dyslipidemia, hypertension, obstructive sleep apnea, T2DM). ${ }^{36}$ This comprehensive approach has both advantages and disadvantages (Table 5). Therefore, many factors should be considered when determining coverage under the pharmacy versus medical benefit in managing safety and cost of weight loss medications as indicated in Table 5.

\section{Limitations}

Two limitations to this review should be noted. First, only the pivotal phase 3 randomized controlled trials were included for review. Second, no guidelines outside of the United States were included for a more broad perspective.

\section{Conclusions}

With the FDA approval of lorcaserin and phentermine/ topiramate, health care decision makers have many factors to consider when developing a new strategy to fight obesity and its comorbid conditions. Comparative safety and efficacy, appropriate utilization management, and drug cost are some of the important issues to consider. Despite a great need for new therapies to treat obesity, medications used for weight loss have significant side-effect profiles and contraindications that may limit therapy. An appropriate utilization management strategy should be implemented to ensure patients receive optimal pharmacotherapeutic benefits without being exposed to significant risks.

\section{Authors}

ELIZABETH M. KELLY, PharmD, is Pharmacy Resident, Blue Cross Blue Shield of Michigan/University of Michigan Health Systems; ALEXANDRA A. TUNGOL, PharmD, is Health Care ReformClinical Pharmacist; and LAURIE A. WESOLOWICZ, PharmD, is Director, Pharmacy Services Clinical, Blue Cross Blue Shield of Michigan, Detroit, Michigan.

AUTHOR CORRESPONDENCE: Elizabeth M. Kelly, PharmD, Blue Cross Blue Shield of Michigan/University of Michigan Health Systems, 600 E. Lafayette, Mail Code 512C, Detroit, MI 48226. Tel.: 313.448.6226; Fax: 866.393.8133; E-mail: ekelly@bcbsm.com.

\section{DISCLOSURES}

The authors have no financial interest or affiliation with any company, product, or service listed in this article. The source of funding for this research was Blue Cross Blue Shield of Michigan.

Study concept and design was contributed by all the authors equally. Data were collected by Kelly with the assistance of Tungol and Wesolowicz, and data interpretation was performed by Kelly and Tungol. The manuscript was written by Kelly and Tungol and was revised by all the authors.

\section{REFERENCES}

1. World Health Organization. Obesity and overweight. March 2013. Available at: http://www.who.int/mediacentre/factsheets/fs311/en/. Accessed June 21, 2013

2. National Center for Health Statistics. Health, United States, 2011: with special feature on socioeconomic status and health. Hyattsville, MD. 2012. Available at: http://www.cdc.gov/nchs/data/hus/husll.pdf\#069. Accessed June 21, 2013

3. Kang JG, Park CY. Anti-obesity drugs: a review about their effects and safety. Diabetes Metab J. 2012;36()1):13-25. Available at: http://e-dmj.org/ DOIx.php?id=10.4093/dmj.2012.36.1.13. Accessed June 21, 2013.

4. National Heart, Lung, and Blood Institute. The practical guide: identification, evaluation, and treatment of overweight and obesity in adults. NIH Publication No. 00-4084. October 2000. Available at: http://www.nhlbi.nih. gov/guidelines/obesity/prctgd_c.pdf. Accessed June 21, 2013.

5. U.S. Food and Drug Administration. Drugs. Fen-Phen safety update information. July 17, 2012. Available at: http://www.fda.gov/Drugs/DrugSafety/ PostmarketDrugSafetyInformationforPatientsandProviders/ucm072820.htm. Accessed June 21, 2013. 
6. Daily Med. Meridia (sibutramine hydrochloride) capsule. Abbott Laboratories. August 2010. Available at: http://dailymed.nlm. nih.gov/dailymed/lookup.cfm?setid=c0333e62-bb00-4722-27b6dca6ab4dlebl\#nlm34071-1. Accessed June 21, 2013.

7. U.S. Food and Drug Administration. Orange book: approved drug products with therapeutic equivalence evaluations. May 17, 2013. Available at: http://www.accessdata.fda.gov/scripts/cder/ob/docs/tempai.cfm. Accessed June 21, 2013.

8. Begley, S. As America's waistline expands, costs soar. Reuters. April 30, 2012. Available at: http://www.reuters.com/article/2012/04/30/us-obesityidUSBRE83T0C820120430. Accessed June 21, 2013.

9. Centers for Disease Control and Prevention. CDC newsroom. Press briefing transcript. CDC weight of the nation press briefing. May 7, 2012. Available at: http://www.cdc.gov/media/releases/2012/t0507_weight_nation. html. Accessed June 21, 2013.

10. Centers for Disease Control and Prevention. Healthy weight - it's not a diet, it's a lifestyle! Balancing calories. October 31, 2011. Available at: http:// www.cdc.gov/healthyweight/calories/index.html. Accessed June 21, 2013.

11. Grundy SM, Hansen B, Smith SC Jr, Cleeman JI, Kahn R. Clinical management of metabolic syndrome: report of the American Heart Association/ National Heart, Lung, and Blood Institute/American Diabetes Association conference on scientific issues related to management. Arterioscler Thromb Vasc Biol. 2004;24(2):e19-e24. Available at: http://atvb.ahajournals.org/content/24/2/e19.full.pdf+html. Accessed June 21, 2013

12. Katzmarzyk PT, Lear SA. Physical activity for obese individuals: a systematic review of effects on chronic disease risk factors. Obes Rev. 2012;13(2):95-105

13. National Institutes of Health. National Heart, Lung, and Blood Institute. Third Report of the National Cholesterol Education Program (NCEP) Expert Panel on Detection, Evaluation, and Treatment of High Blood Cholesterol in Adults (Adult Treatment Panel III) executive summary. NIH Publication No. 01-3670. May 2001. Available at: http://www.nhlbi.nih.gov/guidelines/cholesterol/atp3xsum.pdf. Accessed June 21, 2013.

14. U.S. Preventive Services Task Force. Screening for and management of obesity in adults: U.S. Preventive Services Task Force recommendation statement. AHRQ Publication No. 11-05159-EF-2. June 2012. Available at: http:// www.uspreventiveservicestaskforce.org/uspstf1l/obeseadult/obesers.htm. Accessed June 21, 2013

15. American Diabetes Association. Standards of medical care in diabetes-2013. Diabetes Care. 2013;36(Suppl 1):S11-S66. Available at: http://care. diabetesjournals.org/content/36/Supplement_1/S11.full. Accessed June 21, 2013.

16. Hurren KM, Berlie HD. Lorcaserin: an investigational serotonin 2C agonist for weight loss. Am J Health Syst Pharm. 2011;68(21):2029-37.

17. Bai B, Wang Y. The use of lorcaserin in the management of obesity: a critical appraisal. Drug Des Devel Ther. 2010;5:1-7.

18. Rubino DM, Gadde KM. A review of topiramate and phentermine: a combined therapeutic approach for obesity. Clin Lipidol. 2012;7(1):13-25.

19. Qsymia eDossier. Qsymia (phentermine and topiramate extendedrelease) capsules. AMCP eDossier System. Vivus, Inc. October 2012.

20. Qsymia (phentermine and topiramate extended release). Vivus, Inc. Updated April 2013. Available at: http://www.vivus.com/docs/QsymiaPI.pdf. Accessed June 21, 2013.

21. Smith SR, Weissman NJ, Anderson CM, et al. Multicenter, placebocontrolled trial of lorcaserin for weight management. N Engl J Med. 2010;363(3):245-56. Available at: http://www.nejm.org/doi/full/10.1056/ NEJMoa0909809. Accessed June 21, 2013

22. Fidler MC, Sanchez M, Raether B, et al. A one-year randomized trial of lorcaserin for weight loss in obese and overweight adults: the BLOSSOM trial. J Clin Endocrinol Metab. 2011;96(10):3067-77. Available at: http://jcem. endojournals.org/content/96/10/3067.long. Accessed June 21, 2013.
23. O'Neil PM, Smith SR, Weissman NJ, et al. Randomized placebo-controlled clinical trial of lorcaserin for weight loss in type 2 diabetes mellitus: the BLOOM-DM study. Obesity (Silver Spring). 2012;20(7):1426-36.

24. U.S. Food and Drug Administration. Guidance for industry developing products for weight management. Draft guidance. February 2007. Available at: http://www.fda.gov/downloads/Drugs/.../Guidances/ucm071612.pdf. Accessed June 21, 2013.

25. U.S. Food and Drug Administration. Center for Drug Evaluation and Research. Summary review of lorcaserin. Application number 022529. August 7, 2012. Available at: http://www.accessdata.fda.gov/drugsatfda_ docs/nda/2012/022529Origls000SumR.pdf. Accessed June 21, 2013.

26. Colman E, Golden J, Roberts M, Egan A, Weaver J, Rosebraugh C. The FDA's assessment of two drugs for chronic weight management. $N$ Engl J Med. 2012;367(17):1577-79. Available at: http://www.nejm.org/doi/ full/10.1056/NEJMp1211277. Accessed June 21, 2013.

27. Gadde KM, Allison DB, Ryan DH, et al. Effects of low-dose, controlledrelease, phentermine plus topiramate combination on weight and associated comorbidities in overweight and obese adults (CONQUER): a randomized, placebo-controlled, phase 3 trial. Lancet. 2011;377(9774):1341-52.

28. Allison DB, Gadde KM, Garvey WT, et al. Controlled-release phentermine/topiramate in severely obese adults: a randomized controlled trial (EQUIP). Obesity (Silver Spring). 2012;20(2):330-42. Available at: http://www. ncbi.nlm.nih.gov/pmc/articles/PMC3270297/. Accessed June 21, 2013.

29. Walker J. UPDATE: Vivus gets FDA approval to sell diet drug in stores. The Wall Street Journal. April 16, 2013. Available at: http://online.wsj.com/ article/BT-CO-20130416-713870.html?mod=googlenews_wsj. Accessed June 21, 2013

30. Vivus, Inc. VIVUS submits REMS amendment to FDA for Qsymia (phentermine and topiramate extended-release) capsules CIV. News release. October 17, 2012. Available at: http://ir.vivus.com/releasedetail. cfm?ReleaseID=714128. Accessed June 21, 2013.

31. Gefvert A. Why the FDA's approval of lorcaserin is bad news for Orexigen Therapeutics. Seeking Alpha. June 28, 2012. Available at: http:// seekingalpha.com/article/688981-why-the-fda-s-approval-of-lorcaserin-isbad-news-for-orexigen-therapeutics. Accessed June 21, 2013.

32. Edney A. FDA considers faster approval process for obesity drugs. Bloomberg News. October 11, 2012. Available at: http://www.businessweek. com/news/2012-10-11/fda-considers-faster-approval-process-for-obesitydrugs. Accessed June 21, 2013

33. Burton TM. FDA urged to speed approval of drugs. The Wall Street Journal. September 25, 2012. Available at: http://online.wsj.com/article/SB1 0000872396390444083304578018790623838634 .html. Accessed June 21, 2013.

34. Armstrong D, Flinn R. Vivus's weight-loss pill covered by insurers 30\% of the time. Bloomberg News. October 1, 2012. Available at: http://www. bloomberg.com/news/2012-10-01/vivus-s-weight-loss-pill-covered-by-insurers-30-of-the-time.html?cmpid=yhoo. Accessed June 21, 2013.

35. Dey E, Siddiqui Z. Vivus's obesity pill to be covered by Express Scripts Reuters. December 20, 2012. Available at: http://www.reuters.com/article/2012/12/20/us-vivus-obesitydrug-coverage-idUSBRE8BJOKW20121220. Accessed July 3, 2013.

36. Aetna. Clinical policy bulletin: weight reduction medications and programs. Policy. November 20, 2012. Available at: http://www.aetna.com/cpb/ medical/data/1_99/0039.html. Accessed June 21, 2013.

37. Centers for Disease Control and Prevention. Adult obesity facts. August 13, 2012. Available at: http://www.cdc.gov/obesity/data/adult.html. Accessed June 21, 2013

38. U.S. Food and Drug Administration. Medications target longterm weight control. July 17, 2012. Available at: http://www.fda.gov/ ForConsumers/ConsumerUpdates/ucm312380.htm. Accessed June 21, 2013. 
39. Finkelstein EA, Khavjou OA, Thompson H, et al. Obesity and severe obesity forecasts through 2030. Am J Prev Med. 2012;42(6):563-70. Available at: http://download.journals.elsevierhealth.com/pdfs/journals/0749-3797/ PIIS0749379712001468.pdf. Accessed June 21, 2013.

40. GlobalData. Anti-obesity_drug pipeline analysis and market forecasts to 2016. PRLOG Press Release Distribution. January 11, 2010. Available at: http://www.prlog.org/10483087-antiobesity-drug-pipeline-analysis-andmarket-forecasts-to-2016.html. Accessed June 21, 2013.

41. Medi-Span. Price Rx. Walker Kluwers Health. Available at: http://www. medispan.com/drug-pricing-analysis-pricerx.aspx. Accessed June 21, 2013.

42. Stempel J. U.S. court voids drug rep's conviction, cites free speech. Reuters. December 3, 2012. Available at: http://www.reuters.com/article/2012/12/04/us-offlabel-conviction-idUSBRE8B21DC20121204. Accessed June 21, 2013.

43. Belviq (lorcaserin). Arena Pharmaceuticals GmbH. Revised August 2012 Available at: http://us.eisai.com/package_inserts/BelviqPI.pdf. Accessed June 21, 2013.

44. Didrex (benzphetamine hydrochloride tablet). Pharmacia and Upjohn Company. February 5, 2010. Available at: http://www.accessdata.fda.gov/ drugsatfda_docs/label/2010/012427s026lbl.pdf. Accessed June 21, 2013.

45. Tenuate (diethylpropion hydrochloride immediate release tablet). Aventis Pharmaceuticals Company. November 2003. Available at: http://www. accessdata.fda.gov/drugsatfda_docs/label/2004/11722s029,12546s032lbl. pdf. Accessed June 21, 2013.

46. Desoxyn (methamphetamine hydrochloride tablets). Ovation Pharmaceuticals, Inc. March 2007. Available at: http://www.accessdata.fda. gov/drugsatfda_docs/label/2007/005378s026lbl.pdf. Accessed June 21, 2013.
47. Xenical (orlistat). Genentech USA, Inc. January 2012. Available at: http:// www.gene.com/download/pdf/xenical_prescribing.pdf. Accessed June 21, 2013.

48. Alli (orlistat). GlaxoSmithKline. February 2007. Available at: http:// www.accessdata.fda.gov/drugsatfda_docs/label/2007/021887lbl.pdf. Accessed June 21, 2013.

49. Phendimetrazine tartrate (extended release capsules). Epic Pharma, LLC. October 2011. Available at: http://www.accessdata.fda.gov/drugsatfda_docs/ label/2012/018074s034lbl.pdf. Accessed June 21, 2013.

50. Adipex-P (phentermine). Teva Pharmaceuticals USA. January 2012. Available at: http://www.accessdata.fda.gov/drugsatfda_docs/ label/2012/085128s065lbl.pdf. Accessed June 21, 2013.

51. Fishman A. Aminorex to fen/phen: an epidemic foretold. Circulation. 1999;99(1):156-61. Available at: http://circ.ahajournals.org/content/99/1/156.full. Accessed June 21, 2013.

52. Rodgers RJ, Tschöp MH, Wilding JP. Anti-obesity drugs: past present and future. Dis Model Mech. 2012;5(5):621-26. Available at: http://www.ncbi. nlm.nih.gov/pmc/articles/PMC3424459/?report. Accessed June 21, 2013.

53. U.S. Food and Drug Administration. Drugs. FDA announces withdrawal fenfluramine and dexfenfluramine (fen-phen). Updated August 21, 2009. Available at: http://www.fda.gov/Drugs/DrugSafety/ PostmarketDrugSafetyInformationforPatientsandProviders/ucml79871.htm. Accessed June 21, 2013.

54. U.S. Food and Drug Administration. Drugs. Science backgroundsafety of phenylpropanolamine. Updated May 12, 2009. Available at: http:// www.fda.gov/Drugs/DrugSafety/InformationbyDrugClass/ucm150771.htm. Accessed June 21, 2013. 